\title{
N-(1-ADAMANTYLCARBAMOTHIOYL)BENZAMIDES: SYNTHESIS, BIOLOGICAL EVALUATION AND ADME PREDICTIONS
}

\author{
HOREA GURGU ${ }^{1 \#}$, EMIL ȘTEFĂNESCU ${ }^{2 \#}$, DIANA CAMELIA NUȚ $\breve{A ~}^{1 *}$, MIRON TEODOR \\ CĂPROIU ${ }^{4}$, FLOREA DUMITRAŞCU $^{4}$, MARIANA CARMEN CHIFIRIUC ${ }^{5,6}$, CORALIA BLEOTU $^{7}$, \\ GEORGE MIHAI NIȚULESCU ${ }^{1}$, FLAVIAN ŞTEFAN RĂDULESCU ${ }^{3}$, CARMEN LIMBAN ${ }^{1}$
}

\author{
1 "Carol Davila" University of Medicine and Pharmacy, Faculty of Pharmacy, Pharmaceutical Chemistry Department, 6 \\ Traian Vuia Street, 020956, Bucharest, Romania \\ 2 "Carol Davila” University of Medicine and Pharmacy, Faculty of Pharmacy, Pharmacology and Clinical Pharmacy \\ Department, 6 Traian Vuia Street, 020956, Bucharest, Romania \\ 3 “Carol Davila” University of Medicine and Pharmacy, Faculty of Pharmacy, Drug Industry and Pharmaceutical \\ Biotechnologies Department, 6 Traian Vuia Street, 020956, Bucharest, Romania \\ 4 “Costin D. Nenițescu” The Organic Chemistry Centre of Romanian Academy, 202B Splaiul Independenței, 060023, \\ Bucharest, Romania \\ ${ }^{5}$ University of Bucharest, Faculty of Biology, Department of Microbiology, 1-3 Portocalelor Alley, 060101, Bucharest, \\ Romania \\ ${ }^{6}$ University of Bucharest, Research Institute of the University of Bucharest - ICUB, 91-95 Splaiul Independenței, 050095, \\ Bucharest, Romania \\ 7 “Prof. Șt. Nicolau” Institute of Virology, 36 Mihai Bravu Road, 021326, Bucharest, Romania
}

*corresponding author: diananuta@yahoo.com

\#Authors with equal contribution.

\begin{abstract}
This paper presents the synthesis of five novel benzamide derivatives containing adamantane moiety. The compounds structure was proven through elemental analysis, FT-IR, ${ }^{1} \mathrm{H}-\mathrm{NMR}$ and ${ }^{13} \mathrm{C}-\mathrm{NMR}$ spectroscopy. Their therapeutic potential was evaluated by the in vitro testing of the antimicrobial activity. Two different parameters of the antimicrobial activity were determined: minimum inhibitory concentration (MIC) and minimal biofilm eradication concentration (MBEC). Also, an in vitro cytotoxicity study was carried out on Hep-2 cell line. An in silico study of the compounds determined their ADME profile. The study reports the preliminary biological screening of five novel benzamides with adamantane scaffold, that evidenced a good toxicological and ADME profile, thus representing favourable candidates for further studies.
\end{abstract}

\section{Rezumat}

În această lucrare este prezentată sinteza a cinci noi derivaţi ai benzamidei care conţin fragmentul adamantan. Structura compuşilor a fost dovedită prin analiză elementală, spectroscopie FT-IR, ${ }^{1} \mathrm{H}-\mathrm{RMN}$ și ${ }^{13} \mathrm{C}-\mathrm{RMN}$. Potențialul lor terapeutic a fost evaluat prin testarea in vitro a activității antimicrobiene. S-au determinat doi parametri diferiți ai activității antimicrobiene, respectiv: concentrația minimă inhibitorie $(M I C)$ și concentrația minimă de eradicare a biofilmului $(M B E C)$. De asemenea, a fost efectuat un studiu de citotoxicitate in vitro, pe linia celulară HEp-2. Un studiu in silico al compușilor a determinat profilul lor ADME. Studiul raportează screening-ul biologic preliminar a cinci noi benzamide cu fragment de adamantan, care prezintă profil toxicologic și ADME favorabil, prezentând astfel un potențial promițător pentru studii ulterioare.

Keywords: benzamides, adamantane, microbiological assay, cytotoxicity

\section{Introduction}

Fragments of adamantane and thiourea are important components of bioactive molecules, representing veritable building blocks for the pharmaceutical chemistry.

Some of the adamantane derivatives have been already introduced in clinical use: amantadine, rimantadine, adapromine and tromantadine as anti-virals, memantine, a N-methyl-D-aspartate receptor antagonist used in Alzheimer's disease, dopamantine and carmantadine as antiparkinsonian drugs, saxagliptin and vildagliptin, inhibitors of dipeptidyl peptidase 4 as type II antidiabetes, adapalene, an inhibitor of keratinocyte differentiation and proliferation, in the treatment of acne. All these compounds have the adamantane scaffold substituted at 1 position [14].

Compounds with thiourea skeleton are already used as drugs: noxytiolin as anti-infective agents, sulfathiourea as a bacteriostatic sulfamide, loflucarban for its antifungal properties, thiocarlide as anti-tuberculosis drug, burmamide and metiamide for the treatment of peptic ulcer, phenethyl-thiazolyl-thiourea and trovirdin as non-nucleoside reverse transcriptase inhibitors. 
The wide range of pharmacological properties associated with thiourea derivatives makes them important templates for future drugs design. It was reported compounds with thiourea scaffold which have demonstrated the varied biological activities, such as antimicrobial [28], antiparasitic [29], antiviral [13], antitumour [32], antidiabetic [10], anti-inflammatory [23], insecticidal [31], herbicidal [33] and fungicidal properties [27].

Novel 1-(adamantane-1-carbonyl)-3-halophenyl thioureas and 1-(adamantane-1-carbonyl)-3-(2,4,6-trimethylphenyl)thiourea were synthesized and their structural and vibrational properties were determined $[25,26]$, and Al-Omary and co-workers reported the synthesis and crystal structure of the potentially bioactive 1-(adamantan-1-yl)-3-(4-chlorophenyl)thiourea [1].

A series of novel 1-(2-(adamantan-1-yl)- $1 H$-indol-5yl)-3-substituted thiourea derivatives were obtained and evaluated for their anti-proliferative activity, being found active against H460 lung cancer, HepG2 liver cancer and MCF-7 breast cancer cells. The molecular docking studies have shown that some of these derivatives show promising binding affinity and can modulate Nur77 receptor activity. These findings provide a new direction for the development of anticancer agents having as potential therapeutic target this receptor [12].

4-(3-Adamantan-1-yl-thioureido)-N-(2,6-dimethoxypyrimidin-4-yl)benzene-sulfonamide was designed and synthesized by the addition of N-(2,6-dimethoxypyrimidin-4-yl)-4-isothiocyanatobenzenesulfonamide to the 1-aminoadamantane, as potential antitubercular agent. The structure of the synthesized compound was inspired from the second line of antituberculosis pro-drugs thioacetazone, thiocarlide, ethionamide and prothionamide [11].

1-(Adamantane-2-yl)-3-phenyl/benzyl/phenethylthiourea and 1-(1-(adamantan-1-yl)ethyl)-3-phenyl/ benzyl/phenethyl-thiourea have been synthesized and their inhibitory activity against mammalian and human soluble epoxide hydrolase have been examined [5]. Our research group has been involved in the synthesis and biological assay of different thiourea derivatives [16, 17, 19-21, 24].

In the present study, we report the synthesis of five novel N-(1-adamantylcarbamothioyl)benzamides, through a simple and efficient method, employing good atom economy, readily available starting materials, low amounts of solvents and less hazardous synthesis [6]. By variation of different building blocks (phenols, phthalides, adamantanamines) the synthesis can be adapted for obtaining large numbers of compounds with adamantane scaffolds useful in biological screening. The novel compounds were assessed in vitro for their antimicrobial properties against several bacterial and fungal strains, as well as for their cytotoxic activity, and their ADME profile was established by in silico studies, in order to further synthesize and develop potential leading compounds with therapeutic applications.

\section{Materials and Methods}

Chemistry

Reagents and solvents used for the synthesis were purchased from Merck (Darmstadt, Germany).

Melting points were recorded on an Electrothermal 9100 capillary melting point apparatus (Bibby Sci. Ltd, Stone, UK) and are uncorrected.

The IR spectra were measured using a Bruker Vertex 70 FT-IR spectrometer (Bruker Corporation, Billerica, MA, USA), at room temperature, with an attenuated total reflection (ATR) technique.

The ${ }^{1} \mathrm{H}-\mathrm{NMR}$ and ${ }^{13} \mathrm{C}-\mathrm{NMR}$ spectra were recorded in DMSO- $\mathrm{d}_{6}$ with a Varian Gemini 300BB instrument (Varian Medical Systems, Palo Alto, CA, USA) operating at $300 \mathrm{MHz}$ for ${ }^{1} \mathrm{H}$ and $75 \mathrm{MHz}$ for ${ }^{13} \mathrm{C}$, using tetramethylsilane as internal standard.

Elemental analysis was performed on a Perkin-Elmer 2400 Series II CHNS/O Elemental Analyzer (Waltham, MA, USA).

For the efficient synthesis of the novel N-(1-adamantylcarbamothioyl) benzamides (6a-e) we used a four steps approach.

The general synthesis procedure is described in Figure 1 and was performed as described in previous studies $[2-4,15,18,21]$.

For the synthesis of 2-(4-R-phenoxymethyl)benzoic acids (3), phthalide (1) was refluxed with substituted phenols (2), in alkaline medium and the resulting potassium salts of 2-(4-R-phenoxymethyl)benzoic acids gave the corresponding acids (3) by acidification.

The 2-(4-R-phenoxymethyl)benzoic acid chlorides (4), were obtained by treating the corresponding benzoic acids (3) with thionyl chloride using anhydrous 1,2-dichloroethane as reaction medium. The acid chlorides (4) were used in the next step of the synthesis in crude state, after the removal of 1,2-dichloroethane and excess thionyl chloride by distillation under reduced pressure.

The synthesis of N-(1-adamantylcarbamothioyl)benzamides (6a-e)

To a stirred solution of 2-(4-R-phenoxymethyl)benzoic acid chloride $(4)(0.01 \mathrm{~mol})$ in acetone $(15 \mathrm{~mL})$ was added a solution of ammonium thiocyanate $(0.01 \mathrm{~mol})$ in acetone $(5 \mathrm{~mL})$. The reaction mixture was heated for $1 \mathrm{~h}$, to obtain the benzoyl isothiocyanates (5). The mixture was cooled at room temperature and a solution of 1-adamantylamine $(0.01 \mathrm{~mol})$ in acetone $(2 \mathrm{~mL})$ was added and heated under reflux for $8 \mathrm{~h}$. The reaction mixture was poured into cold water, the solid was isolated by filtration. The final compounds 6a-e were purified by recrystallization from isopropanol with active charcoal. 


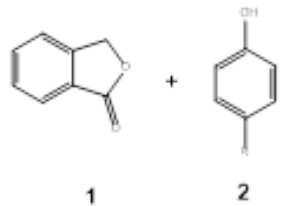

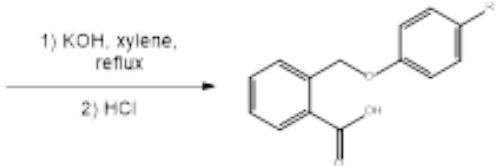

3

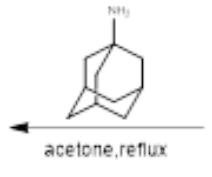

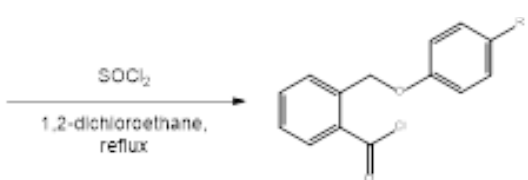

6a-e<smiles>C=C(NC(=O)C12CC3CC(CC(C3)C1)C2)SC(=C)c1ccccc1CCc1ccc(I)cc1</smiles>

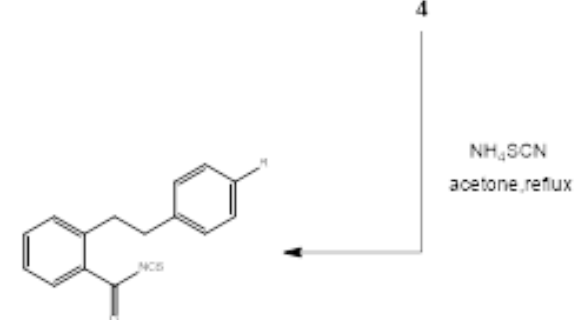

5

$$
\begin{aligned}
& \mathrm{R}: \quad-\mathrm{H} \quad-\mathrm{F} \quad-\mathrm{CH}_{3}^{12} \quad-\mathrm{CH}_{2} \mathrm{CH}_{3} \quad-\mathrm{OCH}_{3} \\
& \begin{array}{lllll}
6 a & 6 b & 6 c & 6 d & 6 e
\end{array}
\end{aligned}
$$

Figure 1.

Synthesis of N-(1-adamantylcarbamothioyl)benzamides 6a-e

\section{Microbiological assays}

The antimicrobial activity of the newly synthesized compounds was investigated on five different microorganisms, respectively Gram-positive: Staphylococcus aureus ATCC 25923, Enterococcus faecalis ATCC 29212 and Gram-negative: Escherichia coli ATCC 25922, Pseudomonas aeruginosa ATCC 27853 bacterial strains, as well as the fungal strain Candida albicans ATCC 10231.

Bacterial suspensions of $0.5 \mathrm{McF}$ arland density obtained from 24 hours microbial cultures developed on solid media were used in the experiments.

The tested compounds were solubilised in DMSO and used for the antimicrobial activity screening at $10 \mathrm{mg} / \mathrm{mL}$ concentration.

The antimicrobial activity of the novel compounds was tested on Muller-Hinton agar medium.

Qualitative screening by disk diffusion method The qualitative screening, of the antimicrobial properties of the tested compounds, was performed by an adapted disk diffusion method. Petri dishes with Muller-Hinton medium were seeded with microbial standardized inoculum as for the classical antibiotic susceptibility testing; then a volume of $10 \mu \mathrm{L}$ of the tested compounds was distributed on the seeded medium, at $30 \mathrm{~mm}$ distance. The plates were left at room temperature for 30 minutes and then incubated at $37^{\circ} \mathrm{C}$ for $24 \mathrm{~h}$. The positive results were read as the occurrence of an inhibition zone of microbial growth around the disk. DMSO was used as negative control for the tested compounds.

Quantitative screening by determination of MIC values Quantitative assay of the antimicrobial activity was performed by binary microdilution method, in MullerHinton broth (MHB) distributed in 96-well plates, in order to establish the MIC. The protocol was performed in accordance with the CLSI guidelines [7, 8]. Serial binary dilutions were prepared starting from stock solution of the tested compounds. In the first well, a volume of $90 \mu \mathrm{L}$ MHB was added with $90 \mu \mathrm{L}$ of tested compound. $90 \mu \mathrm{L}$ were transferred from the first well to the second one and so on until the final well with a compound concentration corresponding to $9.78 \mu \mathrm{g} / \mathrm{mL}$. Each well was seeded with $10 \mu \mathrm{L}$ of microbial inoculum of $0.5 \mathrm{McF}$ arland density. The plates were incubated for $24 \mathrm{~h}$ at $37^{\circ} \mathrm{C}$, and MICs were read as the last concentration of the compound which inhibited the visual microbial growth.

Anti-biofilm activity assay by determination of $M B E C$ values

The anti-biofilm activity was tested by the microtiter method. For this purpose, the microbial strains have been grown in the presence of two-fold serial dilutions of the tested compounds performed in liquid nutrient, distributed in 96-well plates, and incubated for $24 \mathrm{~h}$ at $37^{\circ} \mathrm{C}$. At the end of the incubation period, the plastic wells were emptied, washed three times with sterile distilled water, fixed with cold methanol and stained with $1 \%$ violet crystal solution for 15 minutes. The biofilm formed on plastic wells was resuspended in $33 \%$ acetic acid. The intensity of the coloured suspensions was assessed by measuring the absorbance at $492 \mathrm{~nm}$. The last concentration of the tested compound that inhibited the development of microbial biofilm on the plastic wells was considered the MBEC and was also expressed in $\mu \mathrm{g} / \mathrm{mL}$ [30].

In vitro cytotoxicity assay

The human epidermoid laryngeal carcinoma (HEp-2) cells were maintained in Dulbecco's Modified Eagle Medium: Nutrient Mixture F-12 (DMEM: F12) culture medium, supplemented with $10 \%$ heat-inactivated foetal bovine serum (FBS), penicillin $100 \mathrm{U} / \mathrm{mL}$ and 
streptomycin $100 \mu \mathrm{g} / \mathrm{mL}$. The cytotoxicity treatments were done in triplicate using HEp-2 cells plated in 96-well plates at a density of 10,000 cells per well. After overnight incubation at $37^{\circ} \mathrm{C}$ in a $5 \% \mathrm{CO}_{2}$ incubator, with the tested compounds, the number of remaining live cells was determined using The CellTiter $96^{\mathbb{R}}$ AQueous One Solution Cell Proliferation Assay.

\section{ADME and molecular property predictions}

The chemical structures were written with ACD/ Chemsketch $^{\mathrm{TM}}$ 2016.2, ACD/Labs and their molecular descriptors were generated by ADMET Predictor ${ }^{\mathrm{TM}}$ software, version 8.0.4.6., Simulation Plus Inc.

Drug-like properties of the compounds were determined, in order to apply the Lipinski Rule of five (RO5) criterion: molecular weight (MW, g/mol), n-octanol/ water partition coefficient (Moriguchi, MLogP), number of hydrogen bond donors (HBD), number of hydrogen bond acceptors (HBA).

The computed molecular descriptors were extended to parameters essential for the pharmacokinetic assessment of a drug. Solubility profile was predicted as $\mathrm{Sw}-$ solubility in water $(\mathrm{mg} / \mathrm{mL})$. The estimated penetration through various types of membranes was characterized by: Peff - human jejunal effective permeability $\left(\mathrm{cm} / \mathrm{s} \mathrm{x} 10^{4}\right)$ and MDCK - apparent permeability in Madin-Darby Canine Kidney Cells $(\mathrm{cm} / \mathrm{s} \mathrm{x} \mathrm{107).} \mathrm{Two}$ blood-brain barrier permeation models were applied: BBB - qualitative permeability model and LogBB blood-brain partition coefficient. Other pharmacokinetic predictions include: $\mathrm{Vd}$ - volume of distribution $(\mathrm{L} / \mathrm{kg})$, RBP - blood-to-plasma concentration ratio, Fup percent of drug unbound to plasma proteins (\%) and Pgp_Substr - Likelihood of intestinal efflux by permeability-glycoprotein (P-gp) transporter in human (\%) [9].

\section{Results and Discussion}

\section{Chemistry}

The compounds were obtained through an efficient method, from readily available reagents, with low generation of waste material (no column chromatography is necessary for the purification stages), thus being an environmentally friendly procedure.

The novel benzamides with adamantane scaffold are white or light yellow, crystallized solids, soluble at room temperature in acetone, chloroform, DMSO, after heating in inferior alcohols (methanol, ethanol, isopropanol) and insoluble in water.

Elemental analysis data were in accordance with the calculated values.

In the IR spectra the compounds exhibited absorption bands for $\mathrm{vC}=\mathrm{O}$ in the region $1662-1680 \mathrm{~cm}^{-1} . v \mathrm{~N}-\mathrm{H}$ of the thioamide group appears at $3168-3188 \mathrm{~cm}^{-1}$. Methyl and methylene groups $\mathrm{vC}-\mathrm{H}$ are in the 2904 $2961 \mathrm{~cm}^{-1}$ respectively $2856-2893 \mathrm{~cm}^{-1}$ regions. The vibration for $\delta \mathrm{N}-\mathrm{H}$ amide group is found as a very strong signal at $1502-1536 \mathrm{~cm}^{-1}$. The alkyl-aryl ether bands appear at $1220-1247 \mathrm{~cm}^{-1}$ for the antisymmetric vibration, and at $1019-1032 \mathrm{~cm}^{-1}$ for the symmetric vibration, while the $\mathrm{vC}=\mathrm{S}$ stretching band is in the $1148-1155 \mathrm{~cm}^{-1}$ range. The IR signals are given as $\mathrm{w}$ - weak, $\mathrm{m}$ - medium, $\mathrm{s}$ - strong, vs - very strong.

In the ${ }^{1} \mathrm{H}-\mathrm{NMR}$ spectra, chemical shifts were given as $\delta$ values in parts per million ( $\mathrm{ppm}$ ) relative to tetramethylsilane as internal standard. Coupling constants $J$ were given in $\mathrm{Hz}$. Spin multiplets are given as $\mathrm{s}$ (singlet), d (doublet), t (triplet), q (quartet), $\mathrm{m}$ (multiplet), dd (double doublet), td (triple doublet) and br (broad). The chemical shifts for hydrogen and carbon atoms were established also by homonuclear correlation spectroscopy (COSY), heteronuclear multiple-bond correlation spectroscopy (HMBC) and heteronuclear multiple quantum correlation (HMQC) experiments. The ${ }^{1} \mathrm{H}-\mathrm{NMR}$ data are reported in the following order: chemical shifts, multiplicity, and the coupling constants, number of protons and signal/atom attribution.

In the ${ }^{1} \mathrm{H}-\mathrm{NMR}$ spectra the $\mathrm{NH}$ protons resonated as singlet in the range of $11.19-11.25 \mathrm{ppm}$ and $10.75-10.79 \mathrm{ppm}$. The $-\mathrm{CH}_{2}-\mathrm{O}$ - protons signal was observed in the region $5.16-5.23$ as singlet. The ethyl group protons appear as a triplet at $1.13 \mathrm{ppm}$ for $-\mathrm{CH}_{3}$ group, and as quartet at $2.52 \mathrm{ppm}$ for $-\mathrm{CH}_{2}$ group. The methyl group protons have a signal at $2.22 \mathrm{ppm}$, as singlet. Protons of methoxy group signals are at $3.69 \mathrm{ppm}$, as singlet. In case of the adamantane moiety there are three different signals: 2.17 or $2.18 \mathrm{ppm}$ bs or s for 6 protons, 2.05 or $2.06 \mathrm{ppm}$ bs or s for 3 protons and 1.63 or 1.64 ppm bs or s for 6 protons. The ${ }^{13} \mathrm{C}-\mathrm{NMR}$ data are reported in the following order: chemical shifts and signal/atom attribution. The $\mathrm{C}=\mathrm{O}$ and $\mathrm{C}=\mathrm{S}$ carbons gave signals in the regions 170.18 $170.31 \mathrm{ppm}$, and $177.19-179.75 \mathrm{ppm}$ respectively. The methylene carbon of $-\mathrm{CH}_{2}-\mathrm{O}$ - group appears at $67.33-68.20 \mathrm{ppm}$, the ethyl group carbons appear at $15.97 \mathrm{ppm}\left(-\mathrm{CH}_{3}\right)$ and $27.35 \mathrm{ppm}\left(-\mathrm{CH}_{2}-\right)$. Carbon of methyl group signal is at $19.95 \mathrm{ppm}$ and carbon of methoxy group is at $55.36 \mathrm{ppm}$. There are four different kinds of signals for the adamantane carbons: 54.02 - 54.14 ppm (C-17), 39.68 - 39.71 ppm (C-18; C-19; C-20), 35.79 - 36.65 ppm (C-24; C-25; C-26) and $28.64-28.80$ (C-21; C-22; C-23).

$N$-(1-Adamantylcarbamothioyl)-2-(phenoxymethyl)benzamide (6a)

Yield 67\%; mp $144-145^{\circ} \mathrm{C} .{ }^{1} \mathrm{H}-\mathrm{NMR}: 11.20$ (s, 1H, $\mathrm{NH}$, deuterable); 10.77 (s, 1H, NH, deuterable); 7.56 7.49 (m, 3H, H-4, H-6, H-7); 7.43 (td, $J=7.8 \mathrm{~Hz}, J=$ $2.4 \mathrm{~Hz}, 1 \mathrm{H}, \mathrm{H}-5)$; 7.29 (t, $J=7.8 \mathrm{~Hz}, 2 \mathrm{H}, \mathrm{H}-11, \mathrm{H}-13$ ); 6.97 (t, $J=7.8 \mathrm{~Hz}, 1 \mathrm{H}, \mathrm{H}-12) ; 6.95(\mathrm{~d}, J=7.8 \mathrm{~Hz}, 2 \mathrm{H}$, $\mathrm{H}-10, \mathrm{H}-14$ ); 5.23 (s, 2H, H-8); 2.18 (s, 6H, H-18, H-19, H-20); 2.06 (s, 3H, H-21, H-22, H-23); 1.63 (s, $6 \mathrm{H}, \mathrm{H}-24, \mathrm{H}-25, \mathrm{H}-26) .{ }^{13} \mathrm{C}-\mathrm{NMR}: 177.31$ (C-16); 170.18 (C-1); 158.25 (C-9); 135.38 (C-3); 133.61 (C-2); 130.81 (C-4 or C-6 or C-7); 129.51 (C-11, 
FARMACIA, 2018, Vol. 66, 6

C-13); 128.46 (C-4 or C-6 or C-7); 128.37 (C-4 or C-6 or C-7); 127.84 (C-5); 121.00 (C-12); 114.25 (C-10, C-14); 67.33 (C-8); 54.05 (C-17); 39.69 (C-18, C-19, C-20); 35.80 (C-24, C-25, C-26); 28.79 (C-21, C-22, C-23). FT-IR $\left(v \mathrm{~cm}^{-1}\right): 3184 \mathrm{~m}, 3056 \mathrm{w}, 2904 \mathrm{~s}$, 2889m, 2847m, 1679s, 1597w, 1536vs, 1492s, 1458m, $1354 \mathrm{~m}, 1302 \mathrm{~m}, 1256 \mathrm{~m}, 1243 \mathrm{~s}, 1229 \mathrm{~s}, 1165 \mathrm{~m}, 1149 \mathrm{~s}$, $1125 \mathrm{~m}, 1069 \mathrm{w}, 1032 \mathrm{~m}, 889 \mathrm{w}, 755 \mathrm{~s}, 727 \mathrm{~m}, 688 \mathrm{~m}$, 663m. Anal. calcd. for $\mathrm{C}_{25} \mathrm{H}_{28} \mathrm{~N}_{2} \mathrm{O}_{2} \mathrm{~S}$ (420.57): C, 71.40; H, 6.71; N, 6.66; S, 7.62\%; Found: C, 70.91; H, 6.81; $\mathrm{N}, 6.65 ; \mathrm{S}, 7.67 \%$.

N-(1-Adamantylcarbamothioyl)-2-((4-fluorophenoxy)methyl)benzamide (6b)

Yield 70\%; mp $157-158^{\circ} \mathrm{C} .{ }^{1} \mathrm{H}-\mathrm{NMR}: 11.20$ (s, $1 \mathrm{H}, \mathrm{NH}$, deuterable); 10.76 (s, 1H, NH, deuterable); 7.56 - 7.49 (m, 3H, H-4, H-6, H-7); 7.43 (td, $J=7.8$ Hz, $J=2.4 \mathrm{~Hz}, 1 \mathrm{H}, \mathrm{H}-5) ; 7.13$ (t, $J=9.2 \mathrm{~Hz}, 2 \mathrm{H}, \mathrm{H}-11$, $\mathrm{H}-13) ; 6.96(\mathrm{dd}, J(\mathrm{~F}-\mathrm{H} 10,14)=4.5 \mathrm{~Hz}, J(\mathrm{H} 10,14-$ $\mathrm{H} 11,13)=9.2 \mathrm{~Hz}, 2 \mathrm{H}, \mathrm{H}-10, \mathrm{H}-14) ; 5.21$ (s, 2H, H-8); 2.17 (s, 6H, H-18, H-19, H-20); 2.06 (s, 3H, H-21, $\mathrm{H}-22, \mathrm{H}-23)$; 1.64 (s, 6H, H-24, H-25, H-26). ${ }^{13} \mathrm{C}-$ NMR: 177.19 (C-16); 170.02 (C-1); 156.64 (d, C-12, $J(\mathrm{~F}-\mathrm{C} 12)=234.4 \mathrm{~Hz}) ; 154.45$ (C-9); 135.11 (C-3); 133.55 (C-2); 130.74 (C-4 or C-6 or C-7); 128.43 (C-4 or C-6 or C-7); 128.31 (C-4 or C-6 or C-7); $27.83(\mathrm{C}-5) ; 116.00(\mathrm{~d}, \mathrm{C}-10, \mathrm{C}-14, J(\mathrm{~F}-\mathrm{C} 10,14)=$ $6.9 \mathrm{~Hz}) ; 115.68(\mathrm{~d}, \mathrm{C}-11, \mathrm{C}-13, J(\mathrm{~F}-\mathrm{C} 11,13)=21.7$ $\mathrm{Hz}) ; 68.18$ (C-8); 54.03 (C-17); 39.71 (C-18, C-19, C-20); 35.79 (C-24, C-25, C-26); 28.80 (C-21, C-22, C-23). FT-IR ( $\left.v^{-1} \mathrm{~cm}^{-1}\right): 3182 \mathrm{~m}, 3058 \mathrm{w}, 2904 \mathrm{~s}, 2856 \mathrm{~m}$, $1677 \mathrm{~s}, 1537 \mathrm{vs}, 1502 \mathrm{vs}, 1458 \mathrm{~m}, 1352 \mathrm{~m}, 1300 \mathrm{~m}$, $1247 \mathrm{~m}, 1198 \mathrm{~m}, 1149 \mathrm{~s}, 1123 \mathrm{~m}, 1027 \mathrm{~m}, 831 \mathrm{~m}, 754 \mathrm{~m}$, $731 \mathrm{~m}, 663 \mathrm{w}$. Anal. calcd. for $\mathrm{C}_{25} \mathrm{H}_{27} \mathrm{FN}_{2} \mathrm{O}_{2} \mathrm{~S}$ (438.56): C, 68.47; H, 6.21; F, 4.33; N, 6.39; S, 7.31\%; Found: C, 68.03; H, 6.02; N, 6.29; S, 7.23\%.

$\mathrm{N}$-(1-Adamantylcarbamothioyl)-2-((4-methylphenoxy)methyl)benzamide (6c)

Yield 63\%; mp $140-141^{\circ} \mathrm{C} .{ }^{1} \mathrm{H}-\mathrm{NMR}: 11.20$ (s, $1 \mathrm{H}, \mathrm{NH}$, deuterable); 10.75 (s, 1H, NH, deuterable); 7.54 - 7.50 (m, 3H, H-4, H-6, H-7); 7.42 (td, $J=7.8 \mathrm{~Hz}$, $J=2.4 \mathrm{~Hz}, 1 \mathrm{H}, \mathrm{H}-5) ; 7.08$ (d, $J=8.3 \mathrm{~Hz}, 2 \mathrm{H}, \mathrm{H}-11$, H-13); 6.83 (d, $J=8.3 \mathrm{~Hz}, 2 \mathrm{H}, \mathrm{H}-10, \mathrm{H}-14) ; 5.18$ (s, 2H, H-8); 2.22 (s, 3H, H-12'); 2.17 (bs, 6H, H-18, H-19, H-20); 2.06 (bs, 3H, H-21, H-22, H-23); 1.64 (bs, 6H, H-24, H-25, H-26). ${ }^{13} \mathrm{C}-\mathrm{NMR}: 177.31$ (C-16); 170.19 (C-1); 56.20 (C-9); 129.68 (C-12); 135.56 (C-3); 133.64 (C-2); 130.79 (C-4 or C-6 or C-7); 129.84 (C-11, C-13); 128.47 (C-4 or C-6 or C-7); 128.35 (C-4 or C-6 or C-7); 127.82 (C-5); 114.62 (C-10, C-14); 67.63 (C-8); 54.14 (C-17); 39.68 (C-18, C-19, C-20); 36.65 (C-24, C-25, C-26); 28.64 (C-21, C-22, C-23); 19.95 (C-12'). FT-IR ( $\left.\mathrm{cm}^{-1}\right)$ : $3168 \mathrm{~m}$, 3029w, 2910m, 2886s, 2849m, 1671s, 1544vs, 1508vs, $1456 \mathrm{~m}, 1355 \mathrm{~m}, 1302 \mathrm{w}, 1227 \mathrm{~s}, 1155 \mathrm{~s}, 1121 \mathrm{~m}, 1019 \mathrm{~m}$, $808 \mathrm{w}, 738 \mathrm{~m}, 665 \mathrm{w}$. Anal. calcd. for $\mathrm{C}_{26} \mathrm{H}_{30} \mathrm{~N}_{2} \mathrm{O}_{2} \mathrm{~S}$ (434.60): C, 71.86; H, 6.96; N, 6.45; S, 7.38\%; Found: C, 71.07; H, 6.76; N, 6.49; S, 7.31\%.
N-(1-Adamantylcarbamothioyl)-2-((4-ethylphenoxy)methyl) benzamide (6d)

Yield 65\%; mp $117-118^{\circ} \mathrm{C} .{ }^{1} \mathrm{H}-\mathrm{NMR}: 11.25$ (s, 1H, $\mathrm{NH}$, deuterable); 10.77 (s, 1H, NH, deuterable); 7.60 - 7.38 (m, 4H, H-4- H-7); 7.11 (d, $J=8.7 \mathrm{~Hz}$, 2H, H-11, H-13); 6.86 (d, J=8.6 Hz, 2H, H-10, H-14); 5.18 (s, 2H, H-8); 2.52 (q, $J=7.6 \mathrm{~Hz}, 2 \mathrm{H}, \mathrm{H}-12$ '); 2.17 (bs, 6H, H-18, H-19, H-20); 2.05 (bs, 3H, H-21, H-22, $\mathrm{H}-23) ; 1.63$ (bs, 6H, H-24, H-25, H-26); 1.13 (t, $J=$ $7.6 \mathrm{~Hz}, 3 \mathrm{H}, \mathrm{H}-12$ ”). ${ }^{13} \mathrm{C}-\mathrm{NMR}: 179.75$ (C-16); 170.31 (C-1); 156.25 (C-9); 20.70 (C-12); 136.27 (C-3); $129.67(\mathrm{C}-2) ; 128.54(\mathrm{CH}) ; 128.45(\mathrm{CH}) ; 127.78(\mathrm{CH})$; $127.54(\mathrm{CH}) ; 128.65$ (C-11, C-13); 114.72 (C-10, C-14); 67.57 (C-8); 54.10 (C-17); 39.70 (C-18, C-19, C-20); 35.79 (C-24, C-25, C-26); 28.80 (C-21, C-22, C-23); 27.35 (C-12'); 15.97(C-12”). FT-IR ( $\left.v \mathrm{~cm}^{-1}\right)$ : $3324 \mathrm{w}, 3188 \mathrm{w}, 3058 \mathrm{w}, 2961 \mathrm{~m}, 2895 \mathrm{vs}, 2850 \mathrm{~m}, 1662 \mathrm{~s}$, $1606 \mathrm{w}, 1546 \mathrm{~s}, 1510 \mathrm{vs}, 1451 \mathrm{~m}, 1356 \mathrm{~m}, 1300 \mathrm{~m}, 1220 \mathrm{~s}$, $1148 \mathrm{~m}, 1113 \mathrm{~m}, 1023 \mathrm{~m}, 832 \mathrm{~m}, 812 \mathrm{w}, 707 \mathrm{~m}, 673 \mathrm{w}$. Anal. calcd. for $\mathrm{C}_{27} \mathrm{H}_{32} \mathrm{~N}_{2} \mathrm{O}_{2} \mathrm{~S}$ (448.63): C, 72.29; H, 7.19; N, 6.24; S, 7.15\%; Found: C, 71.76; H, 7.23; N, $6.32 ; \mathrm{S}, 7.19 \%$.

N-(1-Adamantylcarbamothioyl)-2-((4-methoxy-

phenoxy)methyl)benzamide (6e)

Yield 71\%; mp 122 - $123^{\circ} \mathrm{C} .{ }^{1} \mathrm{H}-\mathrm{NMR}: 11.19$ (s, 1H, $\mathrm{NH}$, deuterable); 10.79 (s, 1H, NH, deuterable); 7.58 7.48 (m, 3H, H-4, H-5, H-7); $7.42(\mathrm{td}, J=7.7 \mathrm{~Hz}, J=$ $1.4 \mathrm{~Hz}, 1 \mathrm{H}, \mathrm{H}-6) ; 6.89$ (d, $J=9.4 \mathrm{~Hz}, 2 \mathrm{H}, \mathrm{H}-11, \mathrm{H}-13)$; 6.84 (d, $J=9.4 \mathrm{~Hz}, 2 \mathrm{H}, \mathrm{H}-10, \mathrm{H}-14) ; 5.16$ (s, 2H, H-8); 3.69 (s, 3H, H-12'); 2.18 (bs, 6H, H-18, H-20); 2.06 (bs, 3H, H-21, H-23); 1.64 (bs, 6H, H-24, H-26). ${ }^{13}$ C-NMR: 177.32 (C-16); 170.20 (C-1); 153.69 (C-12); 152.29 (C-9); 135.60 (C-3); 133.67 (C-2); 130.78 (C-4, C-5, C-7); 128.50 (C-4, C-5, C-7); 128.34 (C-4, C-5, C-7); 127.81 (C-6); 115.74 (C-11, C-13); 114.58 (C-10, C-14); 68.20 (C-8); 55.36 (C=12'); 54.05 (C-17); 39.71 (C-18, C-20); 35.80 (C-24, C-26); 28.80 (C-21, C-23). FT-IR $\left(v \mathrm{~cm}^{-1}\right): 3182 \mathrm{~m}, 3057 \mathrm{w}, 2910 \mathrm{~m}, 2879 \mathrm{~m}, 2853 \mathrm{w}$, $2830 \mathrm{w}, 1680 \mathrm{~s}, 1539 \mathrm{vs}, 1506 \mathrm{vs}, 1457 \mathrm{~m}, 1354 \mathrm{~m}, 1304 \mathrm{~m}$, $1256 \mathrm{~m}, 1226 \mathrm{~s}, 1151 \mathrm{~m}, 1124 \mathrm{~m}, 1029 \mathrm{~m}, 1026 \mathrm{~m}, 830 \mathrm{w}$, $751 \mathrm{~m}, 730 \mathrm{~m}, 663 \mathrm{w}$. Anal. calcd. for $\mathrm{C}_{26} \mathrm{H}_{30} \mathrm{~N}_{2} \mathrm{O}_{3} \mathrm{~S}$ (450.60): C, 69.30; H, 6.71; N, 6.22; S, 7.12\%; Found: C, 69.92; H, 6.86; N, 6.29; S, 7.22\%.

Antimicrobial activity

Following the screening of the antimicrobial activity by the disk diffusion method the synthesized compounds (6a-e) exhibited no growth inhibition zones. This result could be explained by the fact that the tested compounds were water-insoluble, and therefore, the active compounds did not diffuse in the culture medium, from the deposited spot.

This limitation is overcome in the quantitative assay performed in liquid medium, which allows a better contact between the tested compounds and the microbial cells. The analysis of the MIC values obtained for the tested compounds showed that they exhibited a slightly increased activity on the fungal strain $C$. albicans, as compared with the bacterial strains 
FARMACIA, 2018, Vol. 66, 6

(Table I). The most resistant strain was Enterococcus faecalis, followed by Staphylococcus aureus. The two Gram-negative strains exhibited similar susceptibility to the tested compounds, as revealed by the same MIC value of $1250 \mu \mathrm{g} / \mathrm{mL}$.

Table I

The MIC $(\mu \mathrm{g} / \mathrm{mL})$ values of the tested compounds

\begin{tabular}{|l|l|c|c|c|c|c|}
\hline \multicolumn{2}{|c|}{ Microbial strains } & \multicolumn{5}{c|}{ Compound $-\mathrm{MIC}(\mu \mathrm{g} / \mathrm{mL})$} \\
\cline { 3 - 7 } & $\mathbf{6 a}$ & $\mathbf{6 b}$ & $\mathbf{6 c}$ & $\mathbf{6 d}$ & $\mathbf{6 e}$ \\
\hline \multirow{2}{*}{$\begin{array}{l}\text { Gram-positive } \\
\text { bacterial strains }\end{array}$} & Staphylococcus aureus ATCC 25923 & 2500 & 2500 & 1250 & 1250 & 1250 \\
\cline { 2 - 7 } & Enterococcus faecalis ATCC 29212 & $>5000$ & $>5000$ & $>5000$ & 5000 & $>5000$ \\
\hline $\begin{array}{l}\text { Gram-negative } \\
\text { bacterial strains }\end{array}$ & Escherichia coli ATCC 25922 & 1250 & 1250 & 1250 & 1250 & 1250 \\
\cline { 2 - 7 } & Pseudomonas aeruginosa ATCC 27853 & 1250 & 1250 & 1250 & 1250 & 1250 \\
\hline Fungal strain & Candida albicans ATCC 10231 & 1250 & 1250 & 625 & 625 & 625 \\
\hline
\end{tabular}

Study of the influence of tested compounds on the development of bacterial biofilms to the inert substratum revealed that, similarly to the MIC assay, the biofilms formed by the Gram-negative strains proved to be more sensitive to the tested compounds, as compared with the Gram-positive strains they have no anti-biofilm activity (Table II). A slight difference could be noticed in the anti-biofilm efficiency of the tested compounds in case of the two Gramnegative strains, the compounds $\mathbf{6 a}, \mathbf{6 b}$ and $\mathbf{6 e}$ being more active on Escherichia coli biofilm, while 6a, $\mathbf{6 b}, \mathbf{6 c}$ and $\mathbf{6 e}$ on Pseudomonas aeruginosa strain. The biofilm quantification could not be performed for the fungal strain which did not show biofilmforming capacity in the experimental conditions.

Table II

The MBEC $(\mu \mathrm{g} / \mathrm{mL})$ values of the tested compounds

\begin{tabular}{|l|l|c|c|c|c|c|}
\hline \multicolumn{2}{|l|}{ Microbial strains } & \multicolumn{5}{c|}{ Compound - MBEC $(\mu \mathrm{g} / \mathrm{mL})$} \\
\cline { 3 - 7 } & $\mathbf{6 a}$ & $\mathbf{6 b}$ & $\mathbf{6 c}$ & $\mathbf{6 d}$ & $\mathbf{6 e}$ \\
\hline \multirow{2}{*}{$\begin{array}{l}\text { Gram-positive } \\
\text { bacterial strains }\end{array}$} & Staphylococcus aureus ATCC 25923 & $>5000$ & $>5000$ & $>5000$ & $>5000$ & $>5000$ \\
\cline { 2 - 7 } & Enterococcus faecalis ATCC 29212 & 2500 & 2500 & 2500 & $>5000$ & 2500 \\
\hline \multirow{2}{*}{$\begin{array}{l}\text { Gram-negative } \\
\text { bacterial strains }\end{array}$} & Escherichia coli ATCC 25922 & 625 & 625 & 2500 & $>5000$ & 625 \\
\cline { 2 - 7 } & Pseudomonas aeruginosa ATCC 27853 & 625 & 625 & 625 & $>5000$ & 625 \\
\hline
\end{tabular}

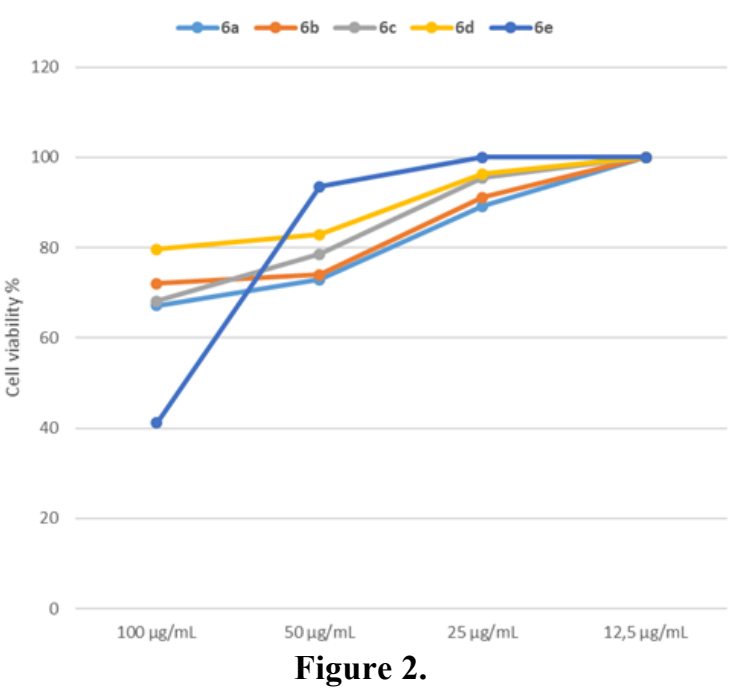

HEp-2 cells viability (\%) in the presence of different concentrations of the tested compounds

The cytotoxicity activity

The results of the cytotoxicity activity have shown that all tested compounds showed no cytotoxicity at the lowest tested concentration, of $12.5 \mu \mathrm{g} / \mathrm{mL}$. The cytotoxicity was very low, with HEp-2 cells preserving their viability over $80 \%$ at $25 \mu \mathrm{g} / \mathrm{mL}$ concentration. In exchange, at higher concentrations, the cytotoxicity of the tested compounds was variable. At $50 \mu \mathrm{g} / \mathrm{mL}$ concentration, only compounds $\mathbf{6 d}$ and $\mathbf{6 e}$ proved a low cytotoxicity, as revealed by HEp- 2 cells viability over $80 \%$, while in case of the highest tested concentration of $100 \mu \mathrm{g} / \mathrm{mL}$, only $\mathbf{6 d}$ exhibited an acceptable cytotoxicity.

Thus, the results of the in vitro cytotoxicity assay indicate that the compounds $\mathbf{6 d}$ and $\mathbf{6 e}$ proved to be the least cytotoxic (Figure 2).

ADME study

The results of the ADME in silico screening are presented in Tables III and IV.

Lipinski's RO5 is a general criterion to assess the drug-like properties of a molecule, with special regard to absorption and permeation. A candidate molecule should have at least 3 of these characteristics: a molecular weight $(\mathrm{MW})<500 \mathrm{~g} / \mathrm{mol}$, logarithm of the compound's partition coefficient between n-octanol and water $(\log \mathrm{P})<5$ (or $\mathrm{M} \log \mathrm{P}<4.15$ ), less than five hydrogen bond donors (HBD) $<5$ and less than ten hydrogen bond acceptors (HBA) $<10$ [22].

Four out of five compounds violated only one of Lipinski's rules and one had none violations (Table III). In case of compound $\mathbf{6 e}$, the presence of a methoxy group proved beneficial for hydrophilic-lipophilic balance of the molecule, fact that also correlates with a lower cytotoxicity in the in vitro test. 
Molecular descriptors in relation to Lipinski RO5

\begin{tabular}{|l|c|c|c|c|c|}
\hline Identifier & $M W(\mathrm{~g} / \mathrm{mol})$ & $H B D$ & $H B A$ & $M \log P$ & Rule of 5 violation \\
\hline 6a & 420.577 & 2 & 2 & $\mathbf{4 . 1 9}$ & 1 \\
\hline 6b & 438.567 & 2 & 3 & $\mathbf{4 . 5 6 1}$ & 1 \\
\hline 6c & 434.604 & 2 & 2 & $\mathbf{4 . 3 9 5}$ & 1 \\
\hline 6d & 448.631 & 2 & 2 & $\mathbf{4 . 5 9 6}$ & 1 \\
\hline 6e & 450.603 & 2 & 3 & 3.875 & 0 \\
\hline
\end{tabular}

Bolded values indicate parameters outside the RO5; $\mathrm{MW}=$ molecular weight; $\mathrm{HBD}=$ hydrogen bond donors; $\mathrm{HBA}=$ hydrogen bond acceptors; Moriguchi octanol-water partition coefficient (MlogP).

In order to better understand the pharmacokinetic profile various physicochemical and biopharmaceutical properties were taken in consideration, from water solubility, to permeability through different membranes or percentage of protein binding.

The predicted water solubility values show a poor solubility profile for $\mathbf{6 a - e}$, all being below the 0.01 threshold. This problem should be addressed in future structural modification by introducing more polar moieties. Thus, being the case of compound 6e which has a slightly higher water solubility.

Regarding membrane permeability, both parameters effective (Peff) and apparent (MDCK) have values over the recommended range. Usually good human jejunal permeability (Peff) is correlated with passive transcellular diffusion [9].

Blood-brain barrier permeation was determined by using two methods. The quantitative BBB model classifies molecules in two categories: low and high

penetration. Compounds that are predicted to have high penetration are evaluated with the regression model $(\log B B)$, which should be over the -0.1 threshold. The good blood-brain barrier permeation profile of 6a-e recommend them for further studies as central nervous system agents.

In case of more specific pharmacokinetic variables, the synthesized compounds exhibited a volume of distribution and blood-to-plasma concentration ratio within limits. Values of RBD over 1.0 suggests partitioning to erythrocytes. On the other hand, all of the compounds are estimated to have high binding affinity to plasma proteins.

$\mathrm{P}$-gp is an efflux membrane transporter, responsible for regulating cellular uptake and distribution of xenobiotics. It is also implicated in many drug-drug interactions. Thus, not being a substrate for P-gp, reduces the chance for 6a-e of unwanted drug interactions and possible side effects.

Table IV

Important computed ADME properties

\begin{tabular}{|l|c|c|c|c|c|c|c|c|c|}
\hline Identifier & $S w$ & Peff & $M D C K$ & $\log B B$ & $B B B$ & $V d$ & $R B P$ & $F_{u p}$ & Pgp_Substr \\
\hline 6a & $\mathbf{0 . 0 0 2}$ & 3.956 & 165.627 & 0.035 & High & 1.199 & 0.843 & $\mathbf{1 . 8 6 4}$ & No (79\%) \\
\hline 6b & $\mathbf{0 . 0 0 1}$ & 3.421 & 176.017 & 0.208 & High & 1.134 & 0.836 & $\mathbf{1 . 6 4 7}$ & No $(68 \%)$ \\
\hline $\mathbf{6 c}$ & $\mathbf{0 . 0 0 1}$ & 3.93 & 114.948 & -0.031 & High & 1.238 & 0.801 & $\mathbf{1 . 5 3}$ & No (75\%) \\
\hline 6d & $\mathbf{0 . 0 0 1}$ & 4.19 & 145.947 & 0.014 & High & 1.275 & 0.806 & $\mathbf{1 . 2 7 5}$ & No (71\%) \\
\hline 6e & $\mathbf{0 . 0 0 3}$ & 2.907 & 147.022 & -0.003 & High & 1.028 & 0.724 & $\mathbf{1 . 8 2 2}$ & No (71\%) \\
\hline
\end{tabular}

Bolded values exceed the recommended ranges: $\mathrm{Sw}(\mathrm{mg} / \mathrm{mL})$ recommended range: $\geq 0.010 ;$ Peff $\left(\mathrm{cm} / \mathrm{s} \mathrm{x} \mathrm{10} 0^{4}\right)$ recommended range: $\geq 0.5$; MDCK $\left(\mathrm{cm} / \mathrm{s} \times 10^{7}\right)$ recommended range: $\geq 30 ;$ LogBB recommended range: $>-0.1 ; \mathrm{Vd}(\mathrm{L} / \mathrm{kg})$ recommended range: $\leq 3.7 ; \mathrm{RBP}$ recommended range: $<1.0 ;$ Fup $(\%)$ recommended range: $>10 \%[9]$.

Overall, the in silico study revealed an ADME profile characterized by low solubility, high permeability and reduced drug interactions. The high permeability is probably induced by the strong lipophilic character of the adamantane moiety.

\section{Conclusions}

We synthesized, characterized and bio-evaluated a novel series of N-(1-adamantylcarbamothioyl)benzamides as potential pharmacological agents.

By variation of the 2-phenoxymethylbenzoic acid and/or of the amine, in this case 1-aminoadamantane, a large series of biologically active products can be obtained.
The method of synthesis is relatively simple. The compounds were easily purified and produced in high yields.

Preliminary biological evaluation revealed that these compounds have no antimicrobial properties.

The reduced cytotoxicity and good ADME profile, especially high permeability through blood-brain barrier recommends these novel benzamides for further studies as potential neurotherapeutic agents.

\section{References}

1. Al-Omary FAM, Ghabbour HA, AlRabiah H, AlAbdullah ES, Crystal structure of 1-(adamantan-1-yl)3-(4-chlorophenyl)thiourea, $\mathrm{C}_{17} \mathrm{H}_{21} \mathrm{ClN}_{2} \mathrm{~S} . Z$ Kristallogr NCS., 2016; 231(3): 707-709.

2. Bădiceanu CD, Missir AV, Chifiriuc MC, Drăcea O, Rauţ I, Larion C, Dițu LM, Mihaescu G, Antimicrobial 
FARMACIA, 2018, Vol. 66, 6

activity of some new 2-thiophene carboxylic acid thioureides. Rom Biotech Lett., 2010; 15(5): 5545-5551.

3. Bădiceanu CD, Nuță DC, Missir AV, Hrubaru M, Delcaru C, Diţu LM, Chifiriuc MC, Limban C, Synthesis, structural, phisico-chemical characterization and antimicrobial activity screening of new thiourea derivatives. Farmacia, 2018; 66(1): 149-156.

4. Bădiceanu CD, Nuță DC, Missir AV, Hrubaru M, Delcaru C, Dițu LM, Chifiriuc MC, Limban C, New derivatives of 2-thiophene carboxylic acid: synthesis, structure and antimicrobial studies. Farmacia, 2018; 66(2): 237-242.

5. Butov GM, Burmistrov VV, Danilov DV, Pitushkin DA, Morisseau C, Hammock BD, Synthesis of adamantyl-containing 1,3-disubstituted diureas and thioureas, efficient targeted inhibitors of human soluble epoxide hydrolase. Russ Chem Bull., 2015; 64(7): 1569-1575.

6. Cioc CR, Ruijter E, Orru VAR, Multicomponent reactions: advanced tools for sustainable organic synthesis. Green Chem., 2014; 16(6): 2958-2975.

7. CLSI document M07-A9. Wayne, PA: Clinical and Laboratory Standards Institute; 2012.

8. CLSI. Methods for Dilution Antimicrobial Susceptibility Tests for Bacteria That Grow Aerobically; Approved Standard $-9^{\text {th }}$ Edition, 2012.

9. El-Saadi MW, Williams-Hart T, Salvatore BA, Mahdavian E, Use of in-silico assays to characterize the ADME profile and identify potential therapeutic targets of fusarochromanone, a novel anti-cancer agent. In Silico Pharmacol., 2015; 3: 6: 1-20.

10. Faidallah HM, Al-Mohammadi MM, Alamry KA, Khan KA, Synthesis and biological evaluation of fluoropyrazolesulfonylurea and thiourea derivatives as possible antidiabetic agents. J Enzyme Inhib Med Chem., 2016; 31(Suppl. 1): 157-163.

11. Ghorab MM, El-Gaby SAM, Soliman MA, Alsaid MS, Abdel-Aziz MM, Elaasser MM, Synthesis, docking study and biological evaluation of some new thiourea derivatives bearing benzenesulfonamide moiety. Chem Cent J., 2017; 11(1): 42: 1-12.

12. Hu H, Lin C, Ao M, Ji Y, Tang B, Zhou X, Fang M, Zeng J, Wu Z, Synthesis and biological evaluation of 1-(2-(adamantane-1-yl)-1H-indol-5-yl)-3-substituted urea/thiourea derivatives as anticancer agents. $R S C$ Adv., 2017; 71: 51640-51651.

13. Karakuş S, Güniz Küçükgüzel S, Küçükgüzel I, De Clercq E, Pannecouque C, Andrei G, Snoeck R, Sahin $\mathrm{F}$, Bayrak OF, Synthesis, antiviral and anticancer activity of some novel thioureas derived from N-(4nitro-2-phenoxyphenyl)-methanesulfonamide. Eur $J$ Med Chem., 2009; 44(9): 3591-3595.

14. Leiva R, Seira C, McBride A, Binnie M, Luque JF, Bidon-Chanal A, Webster SP, Vázquez S, Novel 11bHSD1 inhibitors: C-1 versus $\mathrm{C}-2$ substitution and effect of the introduction of an oxygen atom in the adamantane scaffold. Bioorg Med Chem Lett., 2015; 25: 4250-4253.

15. Limban C, Grumezescu AM, Chirea M, Matei L, Chifiriuc MC, Antimicrobial potential of benzamides and derived nanosystems for controlling in vitro biofilm development on medical devices. Curr Org Chem., 2013; 17 (2): 162-175.
16. Limban C, Missir AV, Căproiu MT, Grumezescu AM, Chifiriuc MC, Bleotu C, Măruțescu L, Papacocea MT, Nuță DC, Novel hybrid formulations based on thiourea derivatives and core@shell $\mathrm{Fe}_{3} \mathrm{O}_{4} @ \mathrm{C} 18$ nanostructures for the development of antifungal strategies. Nanomaterials, 2018; 8(1): 47: 1-14.

17. Limban C, Missir AV, Chiriţă IC, Bădiceanu CD, Drăghici C, Balotescu MC, Stamatoiu O, New thioureides of 2-(4-methyl-phenoxymethyl)-benzoic and 2-(4-methoxy-phenoxymethyl)-benzoic acids with biological activity. Rev Roum Chim., 2008; 53(8): 595-602.

18. Limban C, Missir AV, Chiriță IC, Neagu AF, Drăghici $\mathrm{C}$, Chifiriuc MC, Synthesis and antimicrobial evaluation of some new 2-(4-fluoro-phenoxymethyl)benzoic acid thioureides. Rev Chim (Bucharest), 2011; 62(2): 168173.

19. Limban C, Missir AV, Chiriță IC, Niţulescu GM, Căproiu MT, Chifiriuc MC, Israil AM, Synthesis and antimicrobial properties of new 2-((4-ethylphenoxy) methyl)benzoylthioureas. Chem Pap., 2011; 65(1): 60-69.

20. Limban C, Missir AV, Nuţă DC, Căproiu MT, Papacocea MT, Chiriţă C, Synthesis of some new 2-((4-chlorophenoxy)methyl)-N-(arylcarbamothioyl) benzamides as potential antifungal agents. Farmacia, 2016; 64(5): 775-779.

21. Limban C, Missir AV, Nuță DC, Căproiu MT, Morusciag L, Chiriță C, Cupii A, Gurgu H, Advances in research of new 2-((4-ethylphenoxy)methyl)-N(arylcarbamothioyl)benzamides. Farmacia, 2015; 63(3): 376-380.

22. Lipinski CA, Lombardo F, Dominy BW, Feeney PJ, Experimental and computational approachesto estimate solubility and permeability in drug discovery and development settings. Adv Drug Deliv Rev., 2001; 46: 3-26.

23. Moneer AA, Mohammed KO, El-Nassan HB, Synthesis of novel substituted thiourea and benzimidazole derivatives containing a pyrazolone ring as antiinflammatory agents. Chem Biol Drug Des., 2016; 87(5): 784-793.

24. Nuță DC, Măruțescu L, Missir AV, Morusciag L, Chiriță C, Curuțiu C, Bădiceanu CD, Papacocea MT, Limban $\mathrm{C}$, In vitro evaluation of the antimicrobial activity of N-phenylcarbamothioyl benzamides against planktonic and adherent microbial cells. Rom Biotech Lett., 2017; 22(6): 13163-13168.

25. Saeed A, Bolte M, Erben MF, Pérez H, Intermolecular interactions in crystalline 1-(adamantane-1-carbonyl)3 -substituted thioureas with Hirshfeld surface analysis. Cryst Eng Comm., 2015; 17: 7551-7563.

26. Saeed A, Erben MF, Bolte M, Synthesis, structural and vibrational properties of 1-(adamantane-1-carbonyl)3-halophenyl thioureas. Spectrochim Acta A Mol Biomol Spectrosc., 2013; 102: 408-413.

27. Saeed A, Larik FA, Channar PA, Ismail H, Dilshad E, Mirza B, New 1-octanoyl-3-aryl thiourea derivatives: solvent-free synthesis, characterization and multitarget biological activities. Bangladesh J Pharmacol., 2016; 11: 894-902.

28. Stefanska J, Nowicka G, Struga M, Szulczyk D, Koziol AE, Augustynowicz-Kopec E, Napiorkowska A, Bielenica A, Filipowski W, Filipowska A, Giliberti 
G, Boi S, La Colla P, Sanna G, Antimicrobial and antibiofilm activity of thiourea derivatives incorporating a 2-aminothiazole scaffold. Chem Pharm Bull (Tokyo), 2015; 63(3): 225-236.

29. Stringer T, Taylor D, de Kock C, Guzgay H, Au A, An SH, Sanchez B, O'Connor R, Patel N, Land KM, Smith PJ, Hendricks DT, Egan TJ, Smith GS, Synthesis, characterization, antiparasitic and cytotoxic evaluation of thioureas conjugated to polyamine scaffolds. Eur J Med Chem., 2013; 69: 90-98.

30. Telcian A, Hussien MD, Chifiriuc MC, Bleotu C, Holban AM, Curutiu C, Grosu E, Ficai A, Mihaescu G, Grigore R, Ditu LM, Assessment of the antibiofilm activity and biocompatibility of novel PE and PVC polymers. Rom Biotech Lett., 2017; 22(5): 12997-13004.

31. Wang B, Ma Y, Xiong L, Li Z, Synthesis and insecticidal activity of novel N-pyridylpyrazole carbonyl thioureas. Chin J Chem., 2012; 30(4): 815-821.

32. Yao J, Chen J, He Z, Sun W, Xu W, Design, synthesis and biological activities of thiourea containing sorafenib analogs as antitumor agents. Bioorg Med Chem., 2012; 20(9): 2923-2929.

33. Yonova PA, Stoilkova G, Synthesis and biological activity of urea and thiourea derivatives from 2aminoheterocyclic compounds. J Plant Growth Regul., 2004; 23(4): 280-291. 